\title{
Presence of Mycorrhizal Fungal Hyphae Rather than Living Roots Retards Root Litter Decomposition
}

\author{
Guigang Lin ${ }^{1}$, Zhengxia Chen ${ }^{2}$ and De-Hui Zeng ${ }^{1, *}$ \\ 1 CAS Key Laboratory of Forest Ecology and Management, Institute of Applied Ecology, Chinese Academy of \\ Sciences, Shenyang 110016, China; linguigang@126.com \\ 2 School of Environment, Tsinghua University, Beijing 100084,China; chen_zhengxia@163.com \\ * Correspondence: zengdh@iae.ac.cn; Tel.: +86-24-83970220
}

Received: 17 May 2019; Accepted: 11 June 2019; Published: 13 June 2019

\begin{abstract}
Although both living roots and mycorrhizal fungi are well known to interact with saprotrophic microbes to affect litter decomposition, their relative importance is largely unclear. Here, a two-year pot experiment was conducted with two ectomycorrhizal (Pinus elliottii and Pinus massoniana) and four arbuscular mycorrhizal (Cinnamomum camphora, Cunninghamia lanceolata, Michelia maudiae and Schima superba) subtropical tree species to evaluate the relative effects of living roots and mycorrhizal fungal hyphae on their own root litter decomposition and to test whether these effects differed between ectomycorrhizal and arbuscular mycorrhizal trees. To achieve these objectives, litterbags with $50-\mu \mathrm{m}$ and 1-mm mesh sizes filled with root litter of a given tree species were simultaneously installed in pots planted with the same species and unplanted pots filled with composite soil for all species. Effects of living roots alone were calculated as differences in root litter decomposition between 50- $\mu \mathrm{m}$ and 1-mm mesh litterbags installed in planted pots. Mycorrhizal hyphal effects were calculated as differences in root litter decomposition between $50-\mu \mathrm{m}$ litterbags installed in planted and unplanted pots. The presence of mycorrhizal fungal hyphae significantly reduced root litter mass loss and inhibited the activities of $\beta$-glucosidase and phenol oxidase, while effects of living roots alone were non-significant when all tree species were pooled and inconsistent at the tree species level. Mycorrhizal fungal hyphae induced decreases in root litter mass loss that were markedly related to their inhibitory effects on $\beta$-glucosidase and phenol oxidase activities. When tree species were grouped by their mycorrhizal types, non-significant differences were observed between ectomycorrhizal and arbuscular mycorrhizal trees in their living root or mycorrhizal fungal effects on root litter decomposition. These findings highlight the important roles of mycorrhizal fungi in mediating litter decomposition via interacting with saprotrophic microbes and suggest that changes in tree carbon allocation to mycorrhizal fungi owing to global change may affect soil carbon storage.
\end{abstract}

Keywords: enzyme activity; living root; mycorrhizal fungi; mycorrhizal type; root litter decomposition; root-microbe interaction

\section{Introduction}

Root litter decomposition is an essential process in terrestrial ecosystems, as it releases nutrients for plant growth and returns photosynthetically fixed carbon $(\mathrm{C})$ to the atmosphere [1]. Through producing a suite of hydrolytic and oxidative enzymes, free-living saprotrophic microbes are the most important organisms participating in decomposition processes in soils [2]. Climate, soil conditions and litter chemical traits can affect the activities of saprotrophic microbes and, subsequently, influence root litter decomposition [1]. Furthermore, living roots and their associated mycorrhizal fungi are suggested to affect decomposition by interacting with saprotrophic microbes $[3,4]$. Indeed, root-microbe interactions could play important roles in litter decomposition, given that living roots, mycorrhizal fungi and 
saprotrophic microbes partly share habitats and utilize the same nutrients [5,6]. However, evidence for living root and mycorrhizal fungal effects on root litter decomposition is conflicting, as both positive and negative effects have been reported [3,7]. Consequently, it is still unclear what controls the direction and magnitude of living root and mycorrhizal fungal effects on root litter decomposition.

Several mechanisms, by which living roots influence litter decomposition, have been proposed [4,7]. Living roots can accelerate root litter decomposition via priming effects by releasing root exudates, which fuel the growth of saprotrophic microbes and increase the synthesis of extracellular enzymes $[8,9]$. In contrast, root exudates may retard litter decomposition, considering that saprotrophic microbes could preferentially use easily decomposable exudates as $C$ sources instead of the more recalcitrant root litter [10,11]. Furthermore, living roots may also reduce litter decomposition by other mechanisms, including competing with saprotrophic microbes for soil nutrients and water and exuding antagonistic metabolites that suppress decomposer activities [12,13]. Similar to living roots, mycorrhizal fungal hyphae could affect the activities of saprotrophic microbes and, thus, influence litter decomposition either through exuding easily decomposable C compounds or through nutrient uptake [3,14]. Given their differences in quantity and quality of exudates, mycorrhizal hyphae are expected to differ from living roots in their effects on ecosystem processes [14]. For example, a recent study found that new $\mathrm{C}$ sequestrated in soil was mainly derived from mycorrhizal hyphae rather than living roots [15]. By measuring enzyme activities under elevated $\mathrm{CO}_{2}$, root exudates were shown to contribute more to soil nitrogen $(\mathrm{N})$ cycling, while mycorrhizal fungi contributed more to soil $\mathrm{C}$ cycling [16]. However, whether living roots and mycorrhizal fungi vary in their effects on litter decomposition is currently unknown. This is because previous studies usually either view living roots and mycorrhizal fungi as a whole (i.e., mycorrhiza) to examine their effects on litter decomposition using trenching and girdling experiments [7], or just analyze effects of mycorrhizal hyphae using mesh cores with a chosen size (e.g., $50 \mu \mathrm{m}$ ) that allow the ingrowth of hyphae but not living roots [5].

Although both ectomycorrhizal fungi (ECM) and arbuscular mycorrhizal (AM) fungi can interact with saprotrophic microbes to influence litter decomposition, they may do so in varying directions and magnitudes [4,7]. Some ECM fungi can produce a suite of extracellular enzymes to access organic nutrients directly from litter, which may result in $\mathrm{N}$ limitation for free-living saprotrophic microbes [17]. By contrast, AM fungi have narrow enzymatic capabilities and primarily access inorganic nutrients after organic matter is mineralized by saprotrophic microbes [18,19]. Additionally, compared with AM fungi, ECM fungi acquire more photosynthates from their host plants and have greater standing biomass of external hyphae, which may make them exude more C [20,21]. Given these differences, ECM and AM fungi should vary in their effects on litter decomposition. Indeed, ECM fungi were found to suppress litter decomposition, which was first described by Ruth Gadgil [12]. This phenomenon, named as the 'Gadgil effect', was confirmed by several subsequent studies [6,13]. On the contrary, AM fungi were shown to accelerate litter decomposition through their stimulatory effects on growth and activity of saprotrophic microbes [5]. Although the above-mentioned studies indicate that mycorrhizal type determines fungal effects on litter decomposition, this conclusion should be treated with caution. This is because these studies were conducted under differential soil and climate conditions and did not simultaneously analyze ECM and AM fungal effects. Considering that the magnitude of mycorrhizal fungal effects on litter decomposition depends on soil nutrient availability, soil factors should be held constant to justify whether ECM fungi differ from AM fungi in their effects on litter decomposition [3].

In this study, a pot experiment was conducted to evaluate the relative effects of living roots and mycorrhizal fungal hyphae on root litter decomposition and to test whether these effects are dependent on mycorrhizal types. To achieve these objectives, two ECM and four AM tree species, which are common trees in subtropical forests of China, were selected to study their living root and mycorrhizal hypha effects on root litter decomposition. Litterbags with $50-\mu \mathrm{m}$ and $1-\mathrm{mm}$ mesh sizes filled with root litter of a given tree species were simultaneously installed in pots planted with the same species and unplanted pots. Effects of the living root alone (i.e., not including mycorrhizal hyphal effects) were calculated as differences in root litter decomposition between $50-\mu \mathrm{m}$ and 1 -mm mesh 
litterbags installed in planted pots. Mycorrhizal hyphal effects were calculated as differences in root litter decomposition between 50- $\mu \mathrm{m}$ litterbags installed in planted and unplanted pots. Based on this experimental design, we aimed to answer the following questions: (1) Do mycorrhizal hyphae differ from living roots in their effects on root litter decomposition; and (2) Do mycorrhizal fungal effects on root litter decomposition depend on mycorrhizal types?

\section{Materials and Methods}

\subsection{Material Collection and Preparation}

Root litter and soil samples were collected from Qianyanzhou Ecological Research Station $\left(26^{\circ} 44^{\prime}\right.$ $\mathrm{N}$ and $115^{\circ} 03^{\prime} \mathrm{E}$ ) located in Jiangxi Province, China. This study site has a subtropical monsoon climate with mean annual temperature and precipitation being $17.9^{\circ} \mathrm{C}$ and $1475 \mathrm{~mm}$, respectively. The soil, developed from sandstone and mudstone, is classified as Ultisols according to US Soil Taxonomy.

Root litter of six tree species listed in Table 1 was collected from their monoculture plantations, which were planted on sparse shrubland to combat soil degradation in the 1980s [22]. Among these six species, two Pinus species are ECM trees and the other four are AM trees [19]. In each plantation, eight soil blocks ( $20 \mathrm{~cm}$ length $\times 20 \mathrm{~cm}$ width $\times 20 \mathrm{~cm}$ depth) were excavated using a shovel in April 2013. These soil blocks were carefully loosened to acquire large intact root branches. Collected root branches were gently washed with deionized water to remove adhering soil, and then understory (shrubs and ferns) roots were discarded based on morphology, architecture and color. To acquire sufficient mass, roots of the first five orders (i.e., the sixth- or higher-order roots were cut off from the root branches) were used for the pot experiment, although heterogeneity in chemical traits and decomposition rates is ubiquitous among the first five orders [23]. After air-drying to remove surface adhering water, roots were divided into two subsamples. One subsample was dried at $65^{\circ} \mathrm{C}$ to constant mass to measure water content and then milled $(<0.25 \mathrm{~mm})$ to determine initial chemical traits. The other subsample was used for the pot experiment. The use of fresh roots was to avoid the abscission of low-order roots from root branches during placing roots into litterbags and installing litterbags into pots. After picking out root branches, soil samples were sieved to a 2-mm mesh to remove broken root segments and other debris. After that, soil from these six plantations was thoroughly mixed and then used for the pot experiment within a week. This was done to provide ECM and AM fungal inocula separately for ECM and AM tree seedlings and to ensure the same soil conditions such as nutrient availability and saprotrophic microbes prior to the pot experiment.

Table 1. Mycorrhizal types and initial root litter chemical traits of the studied six tree species. ECM, ectomycorrhizal; AM, arbuscular mycorrhizal; OSF, organic soluble fraction; ASF, acid soluble fraction; AIF, acid insoluble fraction.

\begin{tabular}{|c|c|c|c|c|c|c|c|c|}
\hline Tree Species & $\begin{array}{c}\text { Mycorrhizal } \\
\text { Type }\end{array}$ & $\mathrm{C}(\%)$ & $N\left(m g g^{-1}\right)$ & OSF (\%) & ASF (\%) & AIF (\%) & $\begin{array}{c}\text { C:N } \\
\text { Ratio }\end{array}$ & $\begin{array}{l}\text { AIF:N } \\
\text { Ratio }\end{array}$ \\
\hline Pinus massoniana & ECM & 53.8 & 11.2 & 16.0 & 37.2 & 46.8 & 48.0 & 41.8 \\
\hline Cunninghamia lanceolata & $\mathrm{AM}$ & 57.3 & 15.1 & 11.2 & 28.7 & 60.0 & 38.0 & 39.8 \\
\hline Schima superba & $\mathrm{AM}$ & 52.8 & 13.2 & 13.7 & 35.2 & 51.0 & 40.0 & 38.7 \\
\hline Cinnamomum camphora & $\mathrm{AM}$ & 50.0 & 15.7 & 9.6 & 33.2 & 57.2 & 31.9 & 36.5 \\
\hline
\end{tabular}

\subsection{Pot Experiment}

To distinguish effects of living roots from those of mycorrhizal hyphae on root litter decomposition, our experiment comprised three treatments. For treatment 1, litterbags with a 1-mm mesh size were placed into pots planted with tree seedlings, which allowed the ingrowth of roots plus mycorrhizal hyphae ('+ FR + MH', Figure 1a). For treatment 2, litterbags with a 50- $\mu \mathrm{m}$ mesh size were placed into pots planted with tree seedlings, which allowed the ingrowth of mycorrhizal hyphae but excluded roots (' $\left.-\mathrm{FR}+\mathrm{MH}^{\prime}\right)$. For treatment 3, litterbags with a $50-\mu \mathrm{m}$ mesh size were placed into unplanted 
pots to exclude the effects of roots and mycorrhizal hyphae on root litter decomposition ('- FR $\mathrm{MH}^{\prime}$, Figure 1b). Mesh sizes were chosen based on typical diameters of living roots and mycorrhizal hyphae [24]. Apart from excluding root penetration, compared with 1-mm mesh, mesh size of $50-\mu \mathrm{m}$ could inhibit the colonization of soil fauna with body-size ranging from $50-\mu \mathrm{m}$ to $1-\mathrm{mm}$ (e.g., Collembola and Acari) which could play important roles in litter decomposition [25]. Therefore, effects of living roots on litter decomposition may be confounded by those of soil fauna. To assess the potential effects of soil fauna on litter decomposition, another treatment was added in which 1-mm mesh litterbags were placed into unplanted pots ('fauna control', Figure 1b).


Figure 1. Schematic diagram of the pot experiment design. For a given tree species, there were a planted pot (a) and an unplanted pot (b) per block and each pot contained two litterbags of different mesh sizes (50- $\mu \mathrm{m}$ and 1-mm) filled with root litter of this species. In panel (a), brown and red lines in litterbags represent fine roots (FR) and mycorrhizal hyphae $(\mathrm{MH})$, respectively.

Rectangular pots $(25 \mathrm{~cm}$ length $\times 15 \mathrm{~cm}$ width $\times 20 \mathrm{~cm}$ height) were used to examine the effects of living roots and mycorrhizal hyphae on root litter decomposition. A total of 48 pots were constructed (six tree species $\times$ planted or unplanted $\times$ four replicates). Each pot was filled with $7.5 \mathrm{~kg}$ growth substrates, which consisted of 1:1 mixtures of the above-mentioned soil and washed sand. The growth substrates had the following chemical properties: organic $\mathrm{C}$ of $5.06 \mathrm{mg} \mathrm{g}^{-1}$, total $\mathrm{N}$ of $0.37 \mathrm{mg} \mathrm{g}^{-1}$ and $\mathrm{pH}$ of 4.87. Half of the pots were planted with two-year-old seedlings of the six tree species (four pots per tree species and one seedling per pot). Seedlings of these six tree species were obtained from a commercial nursery located near our study site. Roots of seedlings were washed with deionized water to remove adhering original growth substrates before planting. Initial height and basal diameter of these seedlings ranged from $22.6 \mathrm{~cm}$ to $41.4 \mathrm{~cm}$ and from $2.6 \mathrm{~cm}$ to $4.2 \mathrm{~cm}$, respectively. All pots were moved into a greenhouse without environmental control (i.e., without supplemental lighting and temperature controlling systems), which is near to the site where the six plantations are located (ca. $2 \mathrm{~km}$ ). All pots were arranged on greenhouse benches with a complete randomized block design with four blocks (i.e., replicates). During the experimental period, the positions of the pots in the glasshouse were rearranged once per month to ensure uniform microenvironments. Pots were watered two times per week to maintain a minimum soil water content at $14 \%-16 \%$ (gravimetric content). Additionally, no nutrients were applied during the whole experimental period.

After equilibrating for three months, litterbags $(5 \mathrm{~cm} \times 5 \mathrm{~cm})$ filled with root litter (equivalently $2 \mathrm{~g}$ of oven-dry weight per litterbag) were inserted vertically $10 \mathrm{~cm}$ beneath soil surface of pots in July 2013. For planted pots, two litterbags of different mesh sizes (i.e., 1-mm and 50- $\mu \mathrm{m}$ ) containing root litter of a given tree species were installed in a pot planted with this species (Figure 1a). For unplanted pots, two litterbags of different mesh sizes containing root litter of the same tree species were installed in each unplanted pot (Figure 1b). Thus, for each tree species, there were a planted pot and an unplanted 
pot per block, and each pot contained two litterbags of different mesh sizes filled with root litter of this species, with a total of 96 litterbags.

After a two-year decomposition period, litterbags were retrieved and cleaned by gently washing off adhering soil. For 1-mm mesh litterbags installed in planted pots, in-growing roots were discarded. This can be done because most in-growing roots were still alive, and only few of them turned black and were somewhat shriveled, but still had intact structure. Thus, these in-growing roots can be traced from penetrating points and were isolated from root litter. There was no indication that living roots penetrated $50-\mu \mathrm{m}$ mesh litterbags installed in planted pots. The remaining root litter was weighed and divided into two subsamples. One subsample was used for enzyme assays. The other subsample was dried at $65^{\circ} \mathrm{C}$ to constant mass to measure water content and mass loss. Mass loss was calculated as percentage differences between initial and final weights of root litter. Seedling roots were separated from growth substrates and then washed with deionized water. For each seedling, 50 first-order roots were dissected from root-branching system and used for determining mycorrhizal colonization.

\subsection{Initial Chemical Traits of Root Litter}

$\mathrm{C}$ and $\mathrm{N}$ concentrations of root litter were determined by an elemental analyzer (Vario Microcube, Elementar, Hanau, Germany). Proximate $C$ fractions were measured by sequential extractions [26]. Briefly, milled samples were firstly extracted using acetone and methanol. Organic soluble fraction (OSF) was calculated as differences in weights between the original and extracted samples. Residual materials after the first extraction were divided into acid soluble fraction (ASF) and acid insoluble fraction (AIF) using sulphuric acid digestion.

\subsection{Enzyme Assay}

Owing to the high decomposition rates, remaining root litter of Cinnamomum camphora and Michelia maudiae was not enough for enzyme assays. Two extracellular enzymes related to root litter decomposition, $\beta$-glucosidase (BG) and phenol oxidase (PPO), were determined for root litter of the other four species [27]. Briefly, root litter $(0.5 \mathrm{~g})$ was homogenized in $125 \mathrm{~mL}$ sodium acetate buffer $(\mathrm{pH}=5.0)$ using Vortex-Genie 2 (Scientific Industries, Inc., Bohemia, NY, USA). After that, the potential activities of BG and PPO were determined by fluorimetric and spectrophotometric assays, respectively. For BG, the homogenate and fluorogenically labeled substrate (4-methylumbelliferyl $\mathrm{N}$-acetyl- $\beta$-D-glucosaminide) were pipetted into black 96 -well microplates. The microplates were incubated at $20^{\circ} \mathrm{C}$ for $4 \mathrm{~h}$ and then fluorescence was determined using a microplate fluorometer with $365 \mathrm{~nm}$ excitation and $450 \mathrm{~nm}$ emission filters (Synergy ${ }^{\mathrm{TM}} \mathrm{H} 4$, BioTek, Winooski, VT, USA). For PPO, L-3,4-dihydroxyphenylalanine was used as the substrate and the clear 96-well microplates were incubated at $20^{\circ} \mathrm{C}$ for $18 \mathrm{~h}$. PPO activity was determined by measuring absorbance at $450 \mathrm{~nm}$.

\subsection{Mycorrhizal Colonization of Seedling Roots}

ECM colonization was determined using a dissecting microscope (20× magnification) based on macroscopic features of first-order roots (e.g., color, branching form and diameter). For measuring AM colonization, first-order roots were cleared with $10 \% \mathrm{KOH}$, acidified with $5 \% \mathrm{HCl}$ and then stained with $0.05 \%$ acid fuchsin. AM colonization was determined using a compound light microscope (200x magnification; Leica DM 2500, Wetzlar, Germany) according to the magnified intersection method [28]. Mean ECM colonization of Pinus elliottii and Pinus massoniana roots was separately $80.5 \%$ and $85.5 \%$. Mean AM colonization of seedling roots for C. camphora, Cunninghamia lanceolata, M. maudiae and Schima superba was $66.0 \%, 70.0 \%, 54.5 \%$, and $50.5 \%$, respectively.

\subsection{Calculation and Statistical Analysis}

To separate the effects of living roots from those of mycorrhizal fungi, living root effects were calculated as the differences in mass loss and enzyme activities between the ' $+\mathrm{FR}+\mathrm{MH}^{\prime}$ treatment and the ' $-\mathrm{FR}+\mathrm{MH}^{\prime}$ treatment. Mycorrhizal fungal effects were calculated as the differences in 
mass loss and enzyme activities between the '- FR + $\mathrm{MH}^{\prime}$ treatment and the '- FR - $\mathrm{MH}^{\prime}$ treatment. All these calculations were conducted separately for each tree species within the same block to maintain statistical independence.

We first used a linear mixed model to analyze whether living roots significantly differed from mycorrhizal fungi in their effects on mass loss and enzyme activities, which were conducted separately for each tree species. The first model was fitted with block as a random factor. To test whether living root effects were significantly different from mycorrhizal fungal effects across all the studied tree species, a second linear mixed model was performed. In the second model, block and tree species were included as random factors. Furthermore, a third linear mixed model was conducted to analyze whether ECM trees significantly differed from AM trees in living root effects and mycorrhizal fungal effects. The third model included mycorrhizal type as a fixed factor, and block and tree species nested in mycorrhizal type as random factors. To explore the relationships between changes in mass loss and changes in enzyme activities induced by the presence of living roots and mycorrhizal fungi, a linear mixed regression model was conducted with block and tree species as random factors.

To assess the potential effects of soil fauna on root litter decomposition, a linear mixed model was conducted to analyze whether there were significant differences in root litter mass loss and enzyme activities between 1-mm mesh litterbags and 50- $\mu \mathrm{m}$ mesh litterbags installed in unplanted pots (Figure 1b). In this model, the mesh size and block were included as a fixed factor and a random factor, respectively.

Linear mixed models were carried out using lmer function from the lme4 package in R [29]. $p$-values and marginal $r^{2}$-values were separately obtained from the anova function in the lmerTest package [30] and r.squaredGLMM function in the MuMIn package [31]. No data transformation was conducted since they were normally distributed. The significant level of all above analyses was set at $\alpha=0.05$.

\section{Results}

\subsection{Initial Chemical Traits and Their Relationships with Root Litter Decomposition}

Initial chemical traits of root litter varied widely among the six tree species (Table 1). Specifically, there was 1.7-fold variation in OSF concentration ranging from 9.6\% for C. camphora to $16.0 \%$ for P. massoniana. C:N ratio showed 1.6-fold variation ranging from 30.9 for $M$. maudiae to 48.8 for P. elliottii. AIF:N ratio was highest in P. massoniana and lowest in M. maudiae (Table 1). Mass loss of root litter, decomposed in 50- $\mu \mathrm{m}$ mesh litterbags installed in unplanted pots, revealed about two-fold variation ranging from $39.7 \%$ for $S$. superba to $77.9 \%$ for $M$. maudiae after the two-year decomposition (Figure S1). Pearson correlation showed that root litter mass loss was significantly negatively related to initial AIF:N ratio $(r=-0.83, p=0.04)$, OSF concentration $(r=-0.84, p=0.04)$ and C:N ratio $(r=-0.86$, $p=0.03$; Figure 2).

\subsection{Relative Effects of Living Roots and Mycorrhizal Hyphae on Root Litter Decomposition}

When analyzed across all tree species, compared with effects of living roots alone (calculated as differences in mass loss between the '+ $\mathrm{FR}+\mathrm{MH}^{\prime}$ treatment and the ' $-\mathrm{FR}+\mathrm{MH}^{\prime}$ treatment), mycorrhizal hyphae (calculated as differences in mass loss between the ' $-\mathrm{FR}+\mathrm{MH}$ ' treatment and the '- FR - MH' treatment) had greater inhibitory effects on root litter mass loss $(p<0.01$; Figure 3a) and $\beta$-glucosidase $(p<0.01$; Figure $3 b)$ and phenol oxidase activities $(p<0.01$; Figure 3c). Specifically, the presence of mycorrhizal hyphae markedly reduced root litter mass loss $(-22.7 \%)$, and activities of $\beta$-glucosidase $(-17.9 \%)$ and phenol oxidase $(-18.8 \%)$. However, living roots alone had no significant effects on root litter mass loss (2.3\%; Figure $3 a)$, and activities of $\beta$-glucosidase $(-3.0 \%$; Figure $3 b)$ and phenol oxidase $(-1.2 \%$; Figure $3 \mathrm{c})$. Furthermore, changes in root litter mass loss were markedly positively related to changes in $\beta$-glucosidase (marginal $r^{2}=0.50, p<0.01$; Figure 4a) and phenol 
oxidase (marginal $r^{2}=0.42, p<0.01$; Figure $4 \mathrm{~b}$ ) activities induced by the presence of living roots and mycorrhizal hyphae.

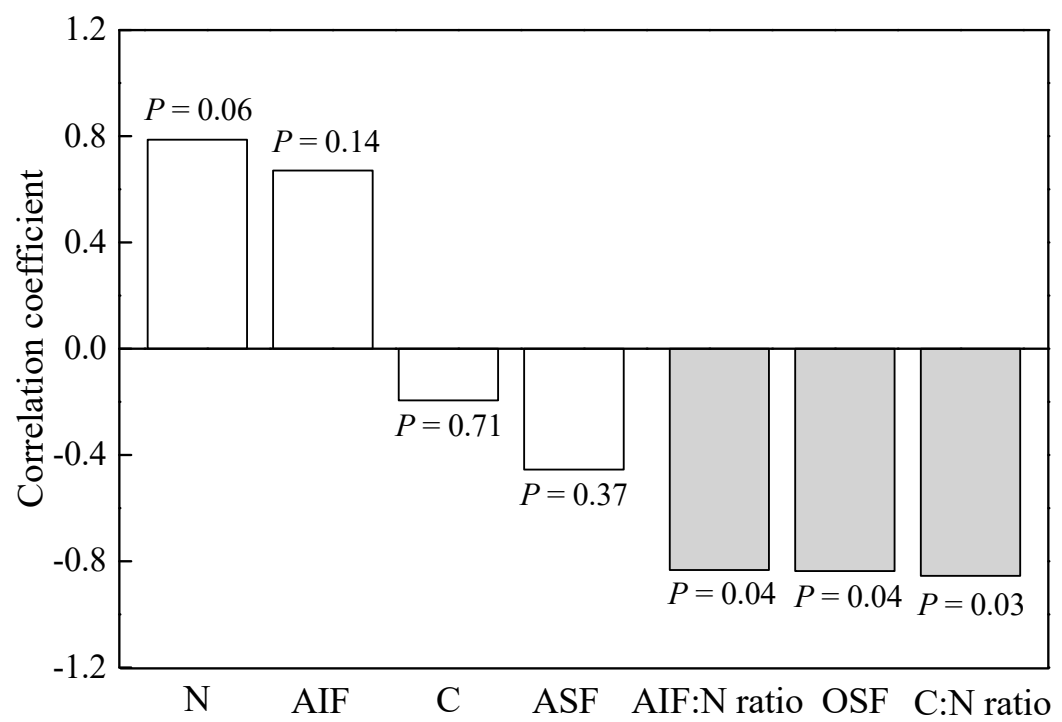

Figure 2. Correlation coefficients between initial chemical traits and root litter mass loss. Mass loss was measured from $50-\mu \mathrm{m}$ mesh litterbags installed in unplanted pots (Figure 1b). Open and gray bars represent non-significant and significant results, respectively. OSF, organic soluble fraction; ASF, acid soluble fraction; AIF, acid insoluble fraction.
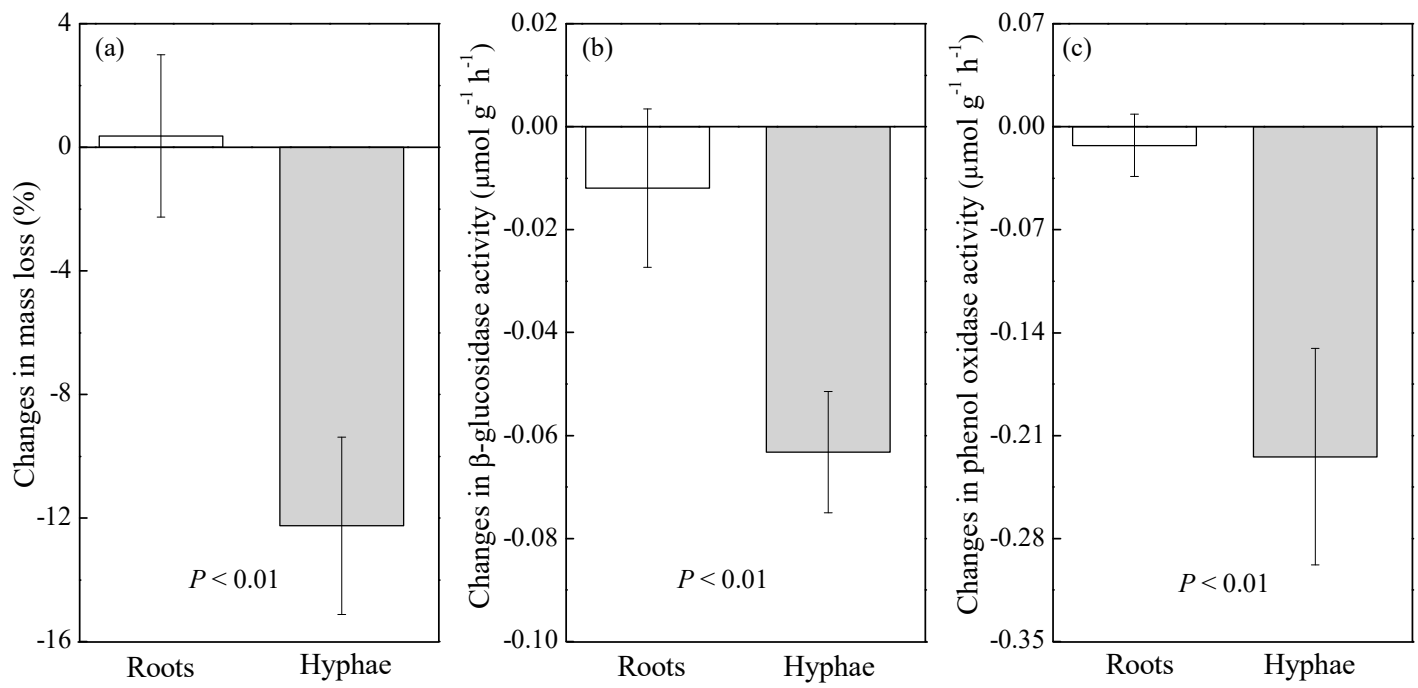

Figure 3. Changes in root litter mass loss (a), and activities of $\beta$-glucosidase (b) and phenol oxidase (c) induced by the presence of living roots (Roots) and mycorrhizal hyphae (Hyphae). $p$-values were obtained from linear mixed models analyzed across all the studied tree species, which were performed to test whether living roots significantly differed from mycorrhizal fungi in their effects on mass loss and enzyme activities. Error bars represent 95\% confidence intervals (CIs). When 95\% CIs do not overlap with $y=0$, the presence of living roots or mycorrhizal fungi significantly affects root litter mass loss and enzyme activities.

To analyze whether ECM and AM trees differed in their living root and mycorrhizal hypha effects, tree species were grouped by their mycorrhizal types. Results revealed that living roots alone of ECM or AM trees had no significant effects on root litter mass loss and enzyme activities (Figure 5). The presence of both ECM and AM hyphae induced significant decreases in root litter mass loss and enzyme activities. Furthermore, no significant differences were found between ECM and AM hyphae 
in their effects on root litter mass loss ( $p=0.29$; Figure $5 a)$, and $\beta$-glucosidase $(p=0.49$; Figure $5 b)$ and phenol oxidase activities ( $p=0.95$; Figure $5 c$ ).
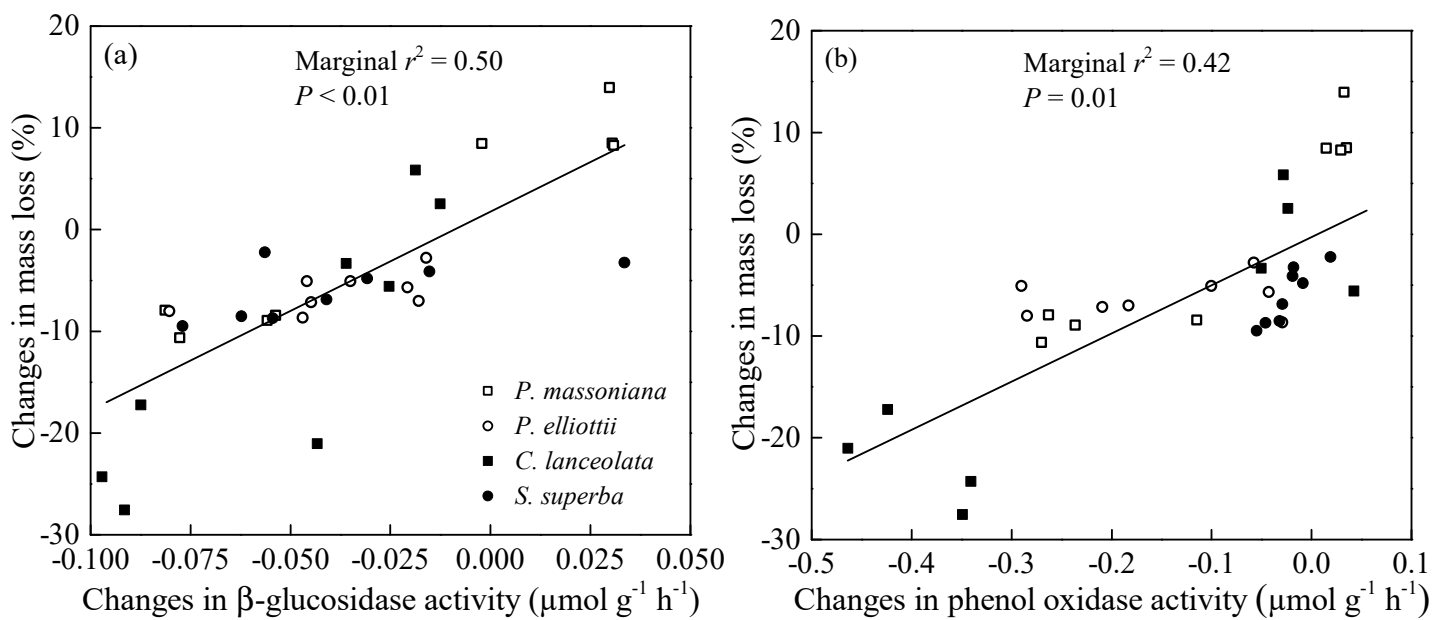

Figure 4. Relationships between changes in root litter mass loss and changes in activities of $\beta$-glucosidase (a) and phenol oxidase (b) induced by the presence of living roots and mycorrhizal hyphae.
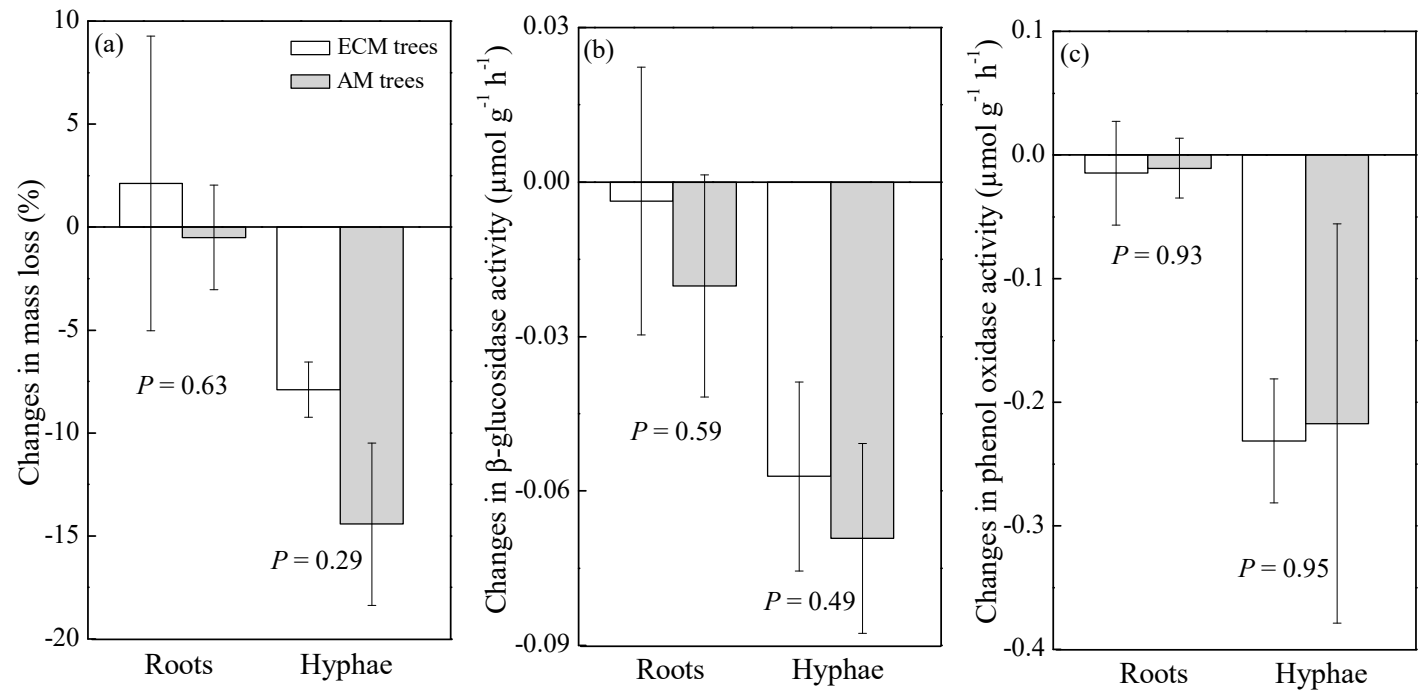

Figure 5. Differences between ectomycorrhizal (ECM) and arbuscular mycorrhizal (AM) trees in their living root (Roots) and mycorrhizal hypha (Hyphae) effects on root litter mass loss (a), and activities of $\beta$-glucosidase (b) and phenol oxidase (c). $P$-values were obtained from linear mixed models, which were conducted to analyze whether there were significant differences between ECM and AM trees in their living root and mycorrhizal hypha effects. Error bars represent $95 \%$ confidence intervals (CIs). When $95 \%$ CIs do not overlap with $y=0$, the presence of living roots or mycorrhizal fungi significantly affects root litter mass loss and enzyme activities.

When analyzed at the tree species level, compared with effects of living roots alone, mycorrhizal hyphae had stronger inhibitory effects on root litter mass loss in five out of the six studied species (Figure 6). Mycorrhizal hyphae had significant negative effects on root litter mass loss for all the studied tree species ranging from $-10.9 \%$ to $-40.4 \%$. Effects of living roots alone on root litter mass loss were mixed. Specifically, living roots of $P$. massoniana significantly accelerated their own root litter decomposition. For P. elliottii and S. superba, their living roots significantly inhibited their own root litter mass loss. Living roots of C. lanceolata, C. camphora and M. maudiae did not significantly influence root litter mass loss (Figure 6). 


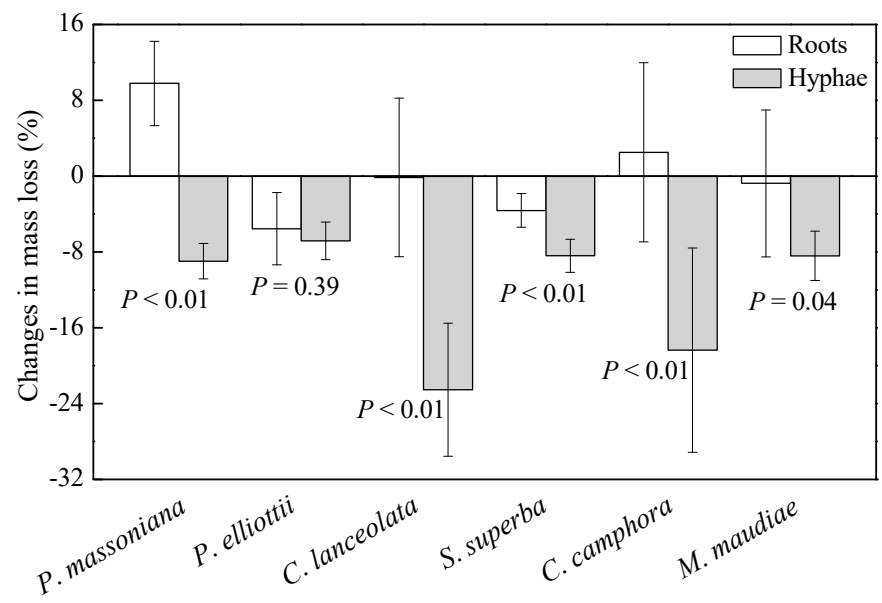

Figure 6. Changes in root litter mass loss induced by the presence of living roots (Roots) and mycorrhizal hyphae (Hyphae). $p$-values were obtained from linear mixed models conducted separately for each tree species, which were performed to analyze whether living roots significantly differed from mycorrhizal fungi in their effects on mass loss. Error bars represent 95\% confidence intervals (CIs). When 95\% CIs do not overlap with $y=0$, the presence of living roots or mycorrhizal hyphae significantly affects root litter mass loss.

Compared with effects of living roots alone, mycorrhizal hyphae had stronger inhibitory effects on $\beta$-glucosidase activities in three out of the four analyzed species (Figure 7a) and phenol oxidase activities in the four analyzed species (Figure $7 \mathrm{~b}$ ). Specifically, mycorrhizal hyphae markedly suppressed $\beta$-glucosidase ( $-11.9 \%--20.3 \%)$ and phenol oxidase activities $(-5.1 \%--29.0 \%)$ in the four analyzed tree species. $\beta$-glucosidase activities were not significantly influenced by living roots of $P$. massoniana and S. superba, but were significantly inhibited by living roots of P. elliottii and C. lanceolata (Figure 7a). Furthermore, phenol oxidase activities were markedly accelerated and suppressed by living roots of P. massoniana and P. elliottii, respectively. Living roots of C. lanceolata and S. superba had no significant effects on phenol oxidase activities (Figure $7 \mathrm{~b}$ ).
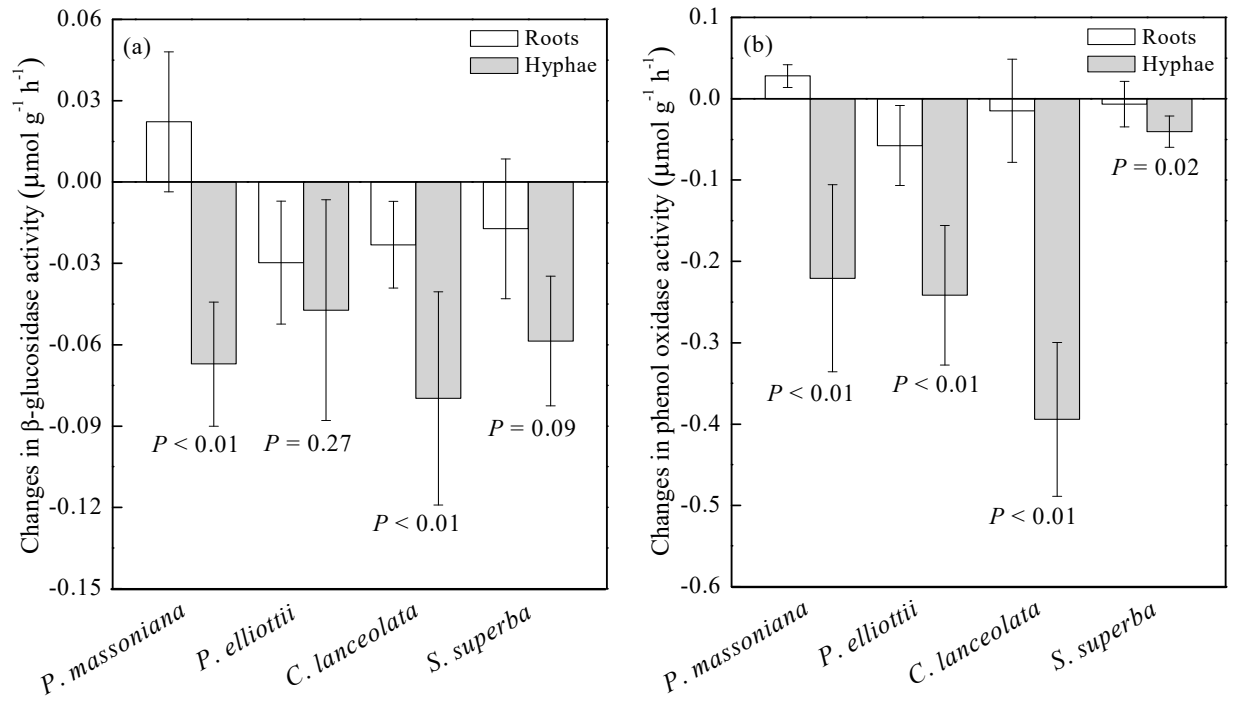

Figure 7. Changes in $\beta$-glucosidase (a) and phenol oxidase (b) activities induced by the presence of living roots (Roots) and mycorrhizal hyphae (Hyphae). $p$-values were obtained from linear mixed models conducted separately for each tree species, which were performed to analyze whether living roots significantly differed from mycorrhizal fungi in their effects on enzyme activities. Error bars represent 95\% confidence intervals (CIs). When 95\% CIs do not overlap with $y=0$, the presence of living roots or mycorrhizal fungi significantly affects enzyme activities. 
To assess the potential effects of soil fauna on root litter decomposition, we analyzed the differences in mass loss and enzyme activities between 1-mm mesh litterbags and $50-\mu \mathrm{m}$ mesh litterbags installed in unplanted plots (Figure 1b). Non-significant differences were found between these two treatments in root litter mass loss (Figure S1) and enzyme activities (Figure S2) for all the studied tree species, indicating that soil fauna may do not play important roles in root litter decomposition in the present study.

\section{Discussion}

Through separating living root effects and mycorrhizal hypha effects, our results showed that, when analyzed across all tree species, the presence of mycorrhizal hyphae markedly reduced root litter mass loss and inhibited the activities of $\beta$-glucosidase and phenol oxidase, while living roots alone (i.e., not including mycorrhizal hyphal effects) had non-significant effects (Figure 3). Mycorrhizal hyphal-induced decreases in root litter mass loss were significantly related to their suppressive effects on enzyme activities (Figure 4). When tree species were grouped by their mycorrhizal types, no significant differences were observed between ECM and AM trees in their living root and mycorrhizal hypha effects on root litter decomposition (Figure 5).When analyzed at the tree species level, in contrast with the consistently negative mycorrhizal hypha effects, living root effects on root litter mass loss and enzyme activities are inconsistent (Figures 6 and 7), indicating that living root effects are species specific and far from generalizable. These findings suggest that mycorrhizal fungi can interact with saprotrophic microbes to influence litter decomposition and that changes in tree $\mathrm{C}$ allocation to mycorrhizal fungi owing to global change may affect soil $\mathrm{C}$ storage.

\subsection{Relative Effects of Living Roots and Mycorrhizal Hyphae on Root Litter Decomposition}

Both living roots and mycorrhizal hyphae can directly and indirectly interact with saprotrophic microbes to influence litter decomposition $[3,4]$. However, their relative effects are largely unclear, because living roots and mycorrhizal hyphae are usually studied together as a whole [16]. In this study, effects of living roots alone and mycorrhizal hyphae were distinguished by calculating the differences in root litter decomposition between the ' $+\mathrm{FR}+\mathrm{MH}^{\prime}$ treatment and the ' $-\mathrm{FR}+\mathrm{MH}^{\prime}$ treatment, and between the ' $-\mathrm{FR}+\mathrm{MH}^{\prime}$ treatment and the ' $-\mathrm{FR}-\mathrm{MH}^{\prime}$ treatment, respectively. Our results showed that mycorrhizal hyphae, but not living roots, markedly reduced their own root litter decomposition when analyzed across all tree species (Figure 3). This inhibitory effect was due to the decreased enzyme activities related to cellulose and lignin decomposition by the presence of mycorrhizal hyphae (Figure 4). Consistent with our findings, a previous study also found that the presence of mycorrhizal hyphae rather than living roots significantly suppressed litter decomposition [32]. In addition, recent studies have shown that mycorrhizal hyphae are more important than living roots in affecting other ecological processes, such as soil organic matter (SOM) decomposition [15,33] and nitrous oxide emissions [34]. However, the opposite pattern was also reported, that living roots played more important roles in influencing litter decomposition [35] and soil bacterial activities [36]. Furthermore, when analyzed at the tree species level, our results revealed that there was a lack of consensus among tree species on whether living roots markedly differed from mycorrhizal hyphae in their effects on root litter decomposition (Figures 6 and 7), thus general patterns may not be made across all tree species or even when tree species were grouped by mycorrhizal types. Owing to these contradictory results drawn from the limited evidence, much more work is still needed to clarify the mechanisms underlying the differential effects of living roots and mycorrhizal hyphae on ecosystem functions.

The stronger suppressive effects of mycorrhizal hyphae on root litter decomposition in this study may be partly attributed to larger amount of labile $C$ exuded by mycorrhizal hyphae relative to living roots, considering that the magnitude of root or mycorrhizal hypha effects depends on the quantity of labile $C$ inputs [37]. Indeed, previous studies have shown that, compared with root derived C, mycorrhizal fungal derived C makes greater contributions to soil new $C$ sequestration $[15,38]$. 
The higher $C$ inputs derived from mycorrhizal hyphae may be due to their fast turnover rates [39] and considerable biomass [40]. In the case of high labile $C$ inputs, saprotrophic microbes may switch to use these easily degradable $C$ as energy sources instead of decomposing recalcitrant root litter, which could result in the decreases in root litter decomposition [10,11].

Another reason for the greater inhibitory effects of mycorrhizal hyphae on root litter decomposition may be that mycorrhizal hyphae acquire larger amounts of nutrients and water than living roots, especially under nutrient limited conditions [41,42]. In our study, the used growth substrates were the mixtures of soil and washed sand, and tree seedlings showed symptoms of nutrient deficiency evidenced by chlorotic leaves and purple leaf margins. In this circumstance, tree seedlings may allocate more photosynthates to mycorrhizal hyphae and mainly rely on hyphae to acquire nutrients and water, since hyphae are much thinner in diameter and then presumably less costly than living roots $[42,43]$. In our pot experiment, more than $80 \%$ of first-order roots of ECM trees were colonized by ECM fungi and root mycorrhizal colonization of AM trees was higher than $50 \%$. These characteristics can permit mycorrhizal hyphae to more thoroughly exploit soil nutrients compared to living roots [43]. The high efficiency of mycorrhizal fungi in nutrient and water uptake could lead to the low availability of nutrients and water limiting saprotrophic activities, which has been suggested to be one of the underlying mechanisms by which mycorrhizal fungi reduce litter decomposition [13,44]. As the pots in the present study were watered two times per week, removal of water by mycorrhizal hyphae cannot explain our results. The sufficient water supply may also reduce the confounding effects of differential water availability induced by varying mesh sizes on root litter decomposition because, relative to 1-mm mesh, 50- $\mu \mathrm{m}$ mesh could be more effective in decreasing water transport and then increase water content of root litter. In contrast, competition between mycorrhizal fungi and saprotrophic microbes for nutrients, especially $\mathrm{N}$, could be a reason for the inhibitory effects of mycorrhizal hyphae on litter decomposition, considering that root litter decomposition was negatively related to initial C:N ratio and AIF:N ratio (Figure 2).

Although our results showed the weaker role of living roots alone in mediating root litter decomposition, one limitation should be noted and need to be addressed for future studies. Owing to the lack of a non-mycorrhizal treatment in which effects of living root alone were assessed in the absence of mycorrhizal fungi, effects of living root alone calculated as differences in mass loss and enzyme activities between the ' $+\mathrm{FR}+\mathrm{MH}^{\prime}$ treatment and the ' $-\mathrm{FR}+\mathrm{MH}^{\prime}$ treatment might be inaccurately estimated. This is because mycorrhizal fungal colonization could influence exudation rates of living roots [45]. For example, several previous studies showed that ECM fungal inoculation reduced root exudation rates $[46,47]$. Thus, the weaker living root alone effects found in our study might be due to the decreases in root exudates in the presence of mycorrhizal fungi, and this possibility cannot be ruled out by our experimental design.

\subsection{Mycorrhizal Type Associated Mycorrhizal Fungal Effects on Root Litter Decomposition}

Inconsistent with the initial hypothesis, non-significant differences were found between ECM and AM fungal hyphae in their effects on root litter decomposition (Figure 5). This finding is surprising, given that ECM fungi and AM fungi are expected to have contrasting effects on decomposition of litter and SOM owing to their differential $\mathrm{N}$ acquisition strategies [18,48]. Specifically, some ECM fungi can produce $\mathrm{N}$-degrading enzymes to mine organic $\mathrm{N}$ directly from organic matter, which may induce $\mathrm{N}$ limitation for saprotrophic microbes and then decelerate decomposition rates [6,17]. By contrast, AM fungi only scavenge inorganic $\mathrm{N}$, thus $\mathrm{N}$ uptake of these fungi relies on saprotrophic decomposition of organic matter [35]. In line with this expectation, a pot experiment simultaneously comparing ECM and AM fungal effects found that AM fungi had greater stimulatory effects on SOM decomposition [48]. Therefore, the opposing effects of ECM and AM fungi on organic matter decomposition should lead to the differences in soil C stocks in their dominated ecosystems. However, previous studies have demonstrated that ECM and AM forests store similar amounts of soil C at the regional [49] and global scales [19]. Although these studies did not directly test the relative effects of ECM and AM fungi on 
SOM decomposition, their results partly support our findings. Considering that our studied ECM trees are from a single genus (Pinus), much more work is needed to examine the generality of our finding by selecting ECM trees as phylogenetically distinct as possible [50].

In line with the 'Gadgil effect', our results revealed that the presence of ECM hyphae significantly suppressed root litter decomposition (Figure 5). Apart from competition for $\mathrm{N}$ with saprotrophic microbes as mentioned above, ECM fungi can also inhibit saprotrophic activities via exuding antagonistic compounds and altering abiotic conditions [3,4]. For example, a previous study has found that Suillus bovinus can suppress the activity of saprotrophic fungi through producing antibiotics and reducing $\mathrm{pH}$ [51]. However, the 'Gadgil effect' did not occur universally, as previous studies also showed that ECM fungi had neutral [7] or even positive [52] effects on litter decomposition. These contradictory results may be due to the different environmental conditions under which these studies were conducted, given that the magnitude of 'Gadgil effect' is expected to be increased with decreasing soil fertility and litter quality, and decreased with soil profile development [3]. In our study, the N-limiting conditions and the destruction of soil stratification of the used growth substrates may make ECM fungi and saprotrophs occupying the same vertical position in the soil profile and targeting the same root litter to acquire $\mathrm{N}$, which can intensify their competition and then reduce litter decomposition.

AM fungi are traditionally known to accelerate litter decomposition via exuding easily available carbohydrates, which can stimulate saprotrophic growth and enzymatic synthesis [5,35]. In contrast with this commonly held view, our results showed that the presence of AM fungal hyphae markedly reduced enzyme activities and decelerated root litter decomposition (Figure 5), which was consistent with previous studies $[44,53,54]$. Two potential mechanisms may be useful in explaining the suppressive effects of AM fungi on root litter decomposition. First, the release of antagonistic metabolites by AM fungal hyphae can reduce the activities of saprotrophs [55]. Second, competition between AM fungi and saprotrophic microbes for inorganic nutrients, especially phosphorus $(\mathrm{P})$, is suggested to suppress litter decomposition [7,44]. Compared with saprotrophic microbes acquiring C from litter or SOM, AM fungi depend on $C$ allocated from host plants, which allow them to produce more hyphae to efficiently scavenge P [42,43]. The high P uptake ability of AM fungi could impose P limitation on saprotrophs under $\mathrm{P}$ limited conditions in which the inhibitory effects of AM fungi on saprotrophic growth have been demonstrated [56]. Considering that $\mathrm{P}$ is a key limiting factor for tree growth in our study site [57], competing with saprotrophic microbes for P may be a plausible reason for the suppressive effects of AM fungi on litter decomposition.

\section{Conclusions}

This study examined the relative effects of living roots and mycorrhizal hyphae on root litter decomposition and analyzed whether these effects associated with mycorrhizal types. Results revealed that the presence of mycorrhizal hyphae significantly reduced root litter mass loss and inhibited enzyme activities related to cellulose and lignin decomposition, while effects of living roots alone were non-significant when analyzed across all tree species and inconsistent at the tree species level. Mycorrhizal hyphae induced reductions in root litter mass loss were significantly related to their inhibitory effects on enzyme activities. When tree species were grouped by mycorrhizal types, non-significant differences were observed between ECM and AM trees in their living root and mycorrhizal hypha effects on root litter decomposition. Our results suggest the important roles of mycorrhizal fungi in mediating litter decomposition via interacting with saprotrophic microbes and highlight the necessity to incorporate mycorrhizal fungal effects into ecosystem models to accurately estimate soil C stocks. 
Supplementary Materials: The following are available online at http://www.mdpi.com/1999-4907/10/6/502/s1, Figure S1: Differences in root litter mass loss between 1-mm and 50- $\mu \mathrm{m}$ mesh litterbags installed in unplanted pots, Figure S2: Differences in activities of $\beta$-glucosidase (a) and phenol oxidase (b) between 1-mm and 50- $\mu \mathrm{m}$ mesh litterbags installed in unplanted pots.

Author Contributions: Conceptualization, G.L. and Z.C.; methodology, G.L. and Z.C.; formal analysis, G.L. and D.-H.Z.; data curation, G.L. and Z.C.; writing-original draft preparation, G.L. and D.-H.Z.; writing-review and editing, Z.C. and D.-H.Z.; funding acquisition, G.L.

Funding: This research was funded by the National Natural Science Foundation of China (Nos. 31700538 and 31830015), the Key Research Program of Frontier Sciences, CAS (No. QYZDB-SSW-DQC002) and the Youth Innovation Promotion Association CAS (No. 2019200).

Acknowledgments: We thank the Qianyanzhou Ecological Research Station for permitting field sampling and the use of the greenhouse.

Conflicts of Interest: The authors declare no conflict of interest.

\section{References}

1. Silver, W.L.; Miya, R.K. Global patterns in root decomposition: Comparisons of climate and litter quality effects. Oecologia 2001, 129, 407-419. [CrossRef] [PubMed]

2. Schneider, T.; Keiblinger, K.M.; Schmid, E. Who is who in litter decomposition? Metaproteomics reveals major microbial players and their biogeochemical functions. ISME J. 2012, 6, 1749-1762. [CrossRef] [PubMed]

3. Fernandez, C.W.; Kennedy, P.G. Revisiting the 'Gadgil effect': Do interguild fungal interactions control carbon cycling in forest soils? New Phytol. 2016, 209, 1382-1394. [CrossRef] [PubMed]

4. Verbruggen, E.; Pena, R.; Fernandez, C.W.; Soong, J.L. Mycorrhizal interactions with saprotrophs and impact on soil carbon storage. In Mycorrhizal Mediation of Soil; Johnson, N.C., Gehring, C., Jansa, J., Eds.; Elsevier: Amsterdam, The Netherlands, 2017; pp. 441-460.

5. Hodge, A.; Campbell, C.D.; Fitter, A.H. An arbuscular mycorrhizal fungus accelerates decomposition and acquires nitrogen directly from organic material. Nature 2001, 413, 297-299. [CrossRef] [PubMed]

6. Averill, C.; Hawkes, C.V. Ectomycorrhizal fungi slow soil carbon cycling. Ecol. Lett. 2016, 19, 937-947. [CrossRef] [PubMed]

7. Brzostek, E.R.; Dragoni, D.; Brown, Z.A.; Phillips, R.P. Mycorrhizal type determines the magnitude and direction of root-induced changes in decomposition in a temperate forest. New Phytol. 2015, 206, 1274-1282. [CrossRef]

8. Wang, F.; Fang, X.; Ding, Z.; Wan, Z.; Chen, F. Effects of understory plant root growth into the litter layer on the leaf litter decomposition of two woody species in a subtropical forest. For. Ecol. Manag. 2016, 364, $39-45$. [CrossRef]

9. Prieto, I.; Birouste, M.; Zamora-Ledezma, E.; Gentit, A.; Goldin, J.; Volaire, F.; Roumet, C. Decomposition rates of fine roots from three herbaceous perennial species: Combined effect of root mixture composition and living plant community. Plant Soil 2017, 415, 359-372. [CrossRef]

10. Kuzyakov, Y. Factors affecting rhizosphere priming effects. J. Plant Nutr. Soil Sci. 2002, 165, 382-396. [CrossRef]

11. Saar, S.; Semchenko, M.; Barel, J.M.; De Deyn, G.B. Legume presence reduces the decomposition rate of non-legume roots. Soil Biol. Biochem. 2016, 94, 88-93. [CrossRef]

12. Gadgil, R.; Gadgil, P.D. Mycorrhiza and litter decomposition. Nature 1971, 233, 133. [CrossRef] [PubMed]

13. Koide, R.T.; Wu, T. Ectomycorrhizas and retarded decomposition in a Pinus resinosa plantation. New Phytol. 2003, 203, 401-407. [CrossRef]

14. Kaiser, C.; Killburn, M.R.; Clode, P.L.; Fuchslueger, L.; Koranda, M.; Cliff, J.B.; Solaiman, Z.M.; Murphy, D.V. Exploring the transfer of recent plant photosynthates to soil microbes: Mycorrhizal pathway vs direct root exudation. New Phytol. 2015, 205, 1537-1551. [CrossRef] [PubMed]

15. Zhang, Z.; Xiao, J.; Yuan, Y.; Zhao, C.; Liu, Q.; Yin, H. Mycelium- and root-derived C inputs differ in their impacts on soil organic $C$ pools and decomposition in forests. Soil Biol. Biochem. 2018, 123, 257-265. [CrossRef]

16. Meier, I.C.; Pritchard, S.G.; Brzostek, E.R.; McCormack, L.; Phillips, R.P. The rhizosphere and hyphosphere differ in their impacts on carbon and nitrogen cycling in forests exposed to elevated $\mathrm{CO}_{2}$. New Phytol. 2015, 205, 1164-1174. [CrossRef] [PubMed] 
17. Lindahl, B.D.; Tunlid, A. Ectomycorrhizal fungi-potential organic matter decomposers, yet not saprotrophs. New Phytol. 2015, 205, 1443-1447. [CrossRef] [PubMed]

18. Phillips, R.P.; Brzostek, E.; Midgley, M.G. The mycorrhizal-associated nutrient economy: A new framework for predicting carbon-nutrient couplings in temperate forests. New Phytol. 2013, 199, 41-51. [CrossRef] [PubMed]

19. Lin, G.; McCormack, M.; Ma, C.; Guo, D. Similar below-ground carbon cycling dynamics but contrasting modes of nitrogen cycling between arbuscular mycorrhizal and ectomycorrhizal forests. New Phytol. 2017, 213, 1440-1451. [CrossRef] [PubMed]

20. Yin, H.; Wheeler, E.; Phillips, R.P. Root-induced changes in nutrient cycling in forests depend on exudation rates. Soil Biol. Biochem. 2014, 78, 213-221. [CrossRef]

21. Lin, G.; Guo, D.; Li, L.; Ma, C.; Zeng, D. Contrasting effects of ectomycorrhizal and arbuscular mycorrhizal tropical tree species on soil nitrogen cycling: The potential mechanisms and corresponding adaptive strategies. Oikos 2018, 127, 518-530. [CrossRef]

22. Li, C.; Li, Q.; Qiao, N.; Xu, X.; Li, Q.; Wang, H. Inorganic and organic nitrogen uptake by nine dominant subtropical tree species. iForest 2015, 9, 253-258. [CrossRef]

23. Lin, G.; Zeng, D. Heterogeneity in decomposition rates and annual litter inputs within fine-root architecture of tree species: Implications for forest soil carbon accumulation. For. Ecol. Manag. 2017, 389, 386-394. [CrossRef]

24. Johnson, D.; Leake, J.R.; Read, D.J. Novel in-growth core system enables functional studies of grassland mycorrhizal mycelial networks. New Phytol. 2001, 152, 555-562. [CrossRef]

25. Bradford, M.A.; Tordoff, G.; Eggers, T.; Jones, H.; Newington, J. Microbiota, fauna, and mesh size interactions in litter decomposition. Oikos 2002, 99, 317-323. [CrossRef]

26. Ryan, M.G.; Melillo, J.M.; Ricca, A. A comparison of methods for determining proximate carbon fractions of forest litter. Can. J. For. Res. 1990, 20, 166-171. [CrossRef]

27. Saiya-Cork, K.R.; Sinsabaugh, R.L.; Zak, D.R. The effects of long term nitrogen deposition on extracellular enzyme activity in an Acer saccharum forest soil. Soil Biol. Biochem. 2002, 34, 1309-1315. [CrossRef]

28. McGonigle, T.P.; Miller, M.H.; Evans, D.L.; Fairchild, G.L.; Swan, J.A. A new method which gives an objective measure of colonization of roots by vesicular-arbuscular mycorrhizal fungi. New Phytol. 1990, 115, 495-501. [CrossRef]

29. Bates, D.; Maechler, M.; Bolker, B.; Walker, S. Fitting linear mixed-effects models using lme4. J. Stat. Softw. 2015, 67, 1-48. [CrossRef]

30. Kuznetsova, A.; Brockhoff, P.B.; Christensen, R.H.B. lmerTest package: Tests in linear mixed effects models. J. Stat. Softw. 2017, 82, 1-26. [CrossRef]

31. Bartoń, K. MuMIn: Multi-Model Inference. R package version 1.40.4. Available online: https://cran.r-project. org/web/packages/MuMIn/index (accessed on 30 January 2018).

32. Gadgil, R.; Gadgil, P.D. Suppression of litter decomposition by mycorrhizal roots of Pinus radiata. N. Z. J. For. Sci. 1975, 5, 33-41.

33. Paterson, E.; Sim, A.; Davidson, J.; Daniell, T.J. Arbuscular mycorrhizal hyphae promote priming of native soil organic matter mineralisation. Plant Soil 2016, 408, 243-254. [CrossRef]

34. Ernfors, M.; Rütting, T.; Klemedtsson, L. Increased nitrous oxide emissions from a drained organic forest soil after exclusion of ectomycorrhizal mycelia. Plant Soil 2011, 343, 161-170. [CrossRef]

35. Nottingham, A.T.; Turner, B.L.; Winter, K.; Chamberlain, P.M.; Stott, A.; Tanner, E.V.J. Root and arbuscular mycorrhizal mycelial interactions with soil microorganisms in lowland tropical forest. FEMS Microbiol. Ecol. 2013, 85, 37-50. [CrossRef]

36. Olsson, P.A.; Bååth, E.; Jakobsen, I.; Söderström, B. Soil bacteria respond to presence of roots but not to mycelium of arbuscular mycorrhizal fungi. Soil Biol. Biochem. 1996, 28, 463-470. [CrossRef]

37. Dijkstra, F.A.; Cheng, W.X. Interactions between soil and tree roots accelerate long-term soil carbon decomposition. Ecol. Lett. 2007, 10, 1046-1053. [CrossRef] [PubMed]

38. Godbold, D.L.; Hoosbeek, M.R.; Lukac, M.; Cotrufo, M.F.; Janssens, I.A.; Ceulemans, R.; Polle, A.; Velthorst, E.J.; Scarascia-Mugnozza, G.; De Angelis, P.; et al. Mycorrhizal hyphal turnover as a dominant process for carbon input into soil organic matter. Plant Soil 2006, 281, 15-24. [CrossRef]

39. Staddon, P.L.; Ramsey, C.B.; Ostle, N.; Ineson, P.; Fitter, A.H. Rapid turnover of hyphae of mycorrhizal fungi determined by AMS microanalysis of ${ }^{14} \mathrm{C}$. Science 2003, 300, 1138-1140. [CrossRef] [PubMed] 
40. Högberg, M.N.; Högberg, P. Extramatrical ectomycorrhizal mycelium contributes one-third of microbial biomass and produces, together with associated roots, half the dissolved organic carbon in soil. New Phytol. 2002, 154, 791-795. [CrossRef]

41. Hobbie, J.E.; Hobbie, E.A. ${ }^{15} \mathrm{~N}$ in symbiotic fungi and plants estimates nitrogen and carbon flux rates in arctic tundra. Ecology 2006, 87, 816-822. [CrossRef]

42. Smith, S.E.; Smith, F.A. Roles of arbuscular mycorrhizas in plant nutrition and growth: New paradigms from cellular to ecosystem scales. Annu. Rev. Plant Biol. 2011, 62, 227-250. [CrossRef]

43. van der Heijden, M.G.A.; Martin, F.M.; Selosse, M.A.; Sanders, I.R. Mycorrhizal ecology and evolution: The past, the present, and the future. New Phytol. 2015, 205, 1406-1423. [CrossRef] [PubMed]

44. Verbruggen, E.; Jansa, J.; Hammer, E.C.; Rillig, M.C. Do arbuscular mycorrhizal fungi stabilize litter-derived carbon in soil? J. Ecol. 2016, 104, 261-269. [CrossRef]

45. Jones, D.L.; Hodge, A.; Kuzyakov, Y. Plant and mycorrhizal regulation of rhizodeposition. New Phytol. 2004, 163, 459-480. [CrossRef]

46. Meier, I.C.; Avis, P.G.; Phillips, R.P. Fungal communities influence root exudation rates in pine seedlings. FEMS Microbiol. Ecol. 2013, 83, 585-595. [CrossRef] [PubMed]

47. Desai, S.; Naik, D.; Cumming, J.R. The influence of phosphorus availability and Laccaria bicolor symbiosis on phosphate acquisition, antioxidant enzyme activity, and rhizospheric carbon flux in Populus tremuloides. Mycorrhiza 2014, 24, 369-382. [CrossRef] [PubMed]

48. Wurzburger, N.; Brookshire, E.N.J. Experimental evidence that mycorrhizal nitrogen strategies affect soil carbon. Ecology 2017, 98, 1491-1497. [CrossRef] [PubMed]

49. Cheeke, T.E.; Phillips, R.P.; Brzostek, E.R.; Rosling, A.; Bever, J.D.; Fransson, P. Dominant mycorrhizal association of trees alters carbon and nutrient cycling by selecting for microbial groups with distinct enzyme function. New Phytol. 2017, 214, 432-442. [CrossRef] [PubMed]

50. Koele, N.; Dickie, I.A.; Oleksyn, J.; Richardson, S.J.; Reich, P.B. No globally consistent effect of ectomycorrhizal status on foliar traits. New Phytol. 2002, 196, 845-852. [CrossRef] [PubMed]

51. Mucha, J.; Zadworny, M.; Werner, A. Cytoskeleton and mitochondrial morphology of saprotrophs and the pathogen Heterobasidion annosum in the presence of Suillus bovinus metabolites. Mycol. Res. 2009, 113, 981-990. [CrossRef]

52. Trap, J.; Akpa-Vinceslas, M.; Margerie, P.; Boudsocq, S.; Richard, F.; Decaëns, T.; Aubert, M. Slow decomposition of leaf litter from mature Fagus sylvatica trees promotes offspring nitrogen acquisition by interacting with ectomycorrhizal fungi. J. Ecol. 2017, 105, 528-539. [CrossRef]

53. Jannoura, R.; Kleikamp, B.; Dyckmans, J.; Joergensen, R.G. Impact of pea growth and arbuscular mycorrhizal fungi on the decomposition of ${ }^{15} \mathrm{~N}$-labeled maize residues. Biol. Fertil. Soils 2012, 48, 547-560. [CrossRef]

54. Leifheit, E.F.; Verbruggen, E.; Rillig, M.C. Arbuscular mycorrhizal fungi reduce decomposition of woody plant litter while increasing soil aggregation. Soil Biol. Biochem. 2015, 81, 323-328. [CrossRef]

55. Welc, M.; Ravnskov, S.; Kieliszewska-Rokicka, B.; Larsen, J. Suppression of other soil microorganisms by mycelium of arbuscular mycorrhizal fungi in root-free soil. Soil Biol. Biochem. 2010, 42, 1534-1540. [CrossRef]

56. Zhang, L.; Xu, M.G.; Liu, Y.; Zhang, F.S.; Hodge, A.; Feng, G. Carbon and phosphorus exchange may enable cooperation between an arbuscular mycorrhizal fungus and a phosphate-solubilizing bacterium. New Phytol. 2016, 210, 1022-1032. [CrossRef] [PubMed]

57. Chen, F.S.; Niklas, K.J.; Liu, Y.; Fang, X.M.; Wan, S.Z.; Wang, H.M. Nitrogen and phosphorus additions alter nutrient dynamics but not resorption efficiencies of Chinese fir leaves and twigs differing in age. Tree Physiol. 2015, 35, 1106-1117. [CrossRef] [PubMed]

(C) 2019 by the authors. Licensee MDPI, Basel, Switzerland. This article is an open access article distributed under the terms and conditions of the Creative Commons Attribution (CC BY) license (http://creativecommons.org/licenses/by/4.0/). 